\title{
"Because everything was happening despite institutions, despite dominant ideologies, despite everything"1. Ari Sitas, labour studies and general sociology
}

W. Keim²

SAGE (Sociétés, Acteurs, Gouvernement en Europe), CNRS/Strasbourg University, Strasbourg, France

Journal of Contemporary African Studies

Received 31 Jan 2019, Accepted 27 Jul 2020, Published online: 02 Oct 2020, https://doi.org/10.1080/02589001.2020.1805417

\begin{abstract}
This essay to celebrate and honour Ari Sitas draws on my research experience on the development of South African labour studies as a counter hegemonic current. It highlights Ari's theoretical contributions to the field of labour studies, as well as to general sociology. The article discusses with some detail The flight of the Gwala-Gwala bird (2016) as well as Voices that reason, theoretical parables (2004).
\end{abstract}

Keywords: Ari Sitas; labour studies; counter hegemonic current; sociological theory; culture and working life;

I first met Ari Sitas in the early 2000s, at the Sociology Department of the University of Freiburg, where I was completing my Master's and planning a PhD. My idea was to study unequal development within the global social sciences, and to subsequently quit academia and become involved in international cultural, educational and science policy in some way. I needed advice on how to proceed. I sat with Ari, who was then a visiting professor within the Global Studies Program and tried to explain what I wanted to do. I was not sure myself whether I knew really what I wanted to do. He seemed to be quite sure about what I wanted to do, though. Unlike many others who discouraged me from pursuing my project as it was, because it looked unfeasible, he strongly encouraged me to follow up on my ideas and gave valuable input into my first sketches. Ultimately, over the following years, working with him convinced me that sociology was a worthwhile endeavour. I stayed.

In a recent workshop with colleagues, a young researcher expressed her admiration at the fact that in the project I coordinated from 2010-2014 at the University of Freiburg, I spent 1.3 million euros on inviting and supporting little-known junior researchers in the early steps of their career, and on top of that people who did not even master proper English. (She now plans to repeat the experience and do the same). I immediately admitted that this was what I had learned from Ari. The next step was that he pulled me into an ISA Executive meeting that he, in his function as ISA Officer for Program, had convened at Freiburg in order to plan the upcoming world congress in Durban in 2006. There, I stood trying to explain how I perceived global sociology as a highly uneven endeavour, marked by deep centre-periphery divides. It was clear that this made everybody unhappy if not angry. The professors from what I had called the centre did not want to hear that they were dominating and the other did not want to be called peripheral.

Nevertheless, this was worked out as the first part of my PhD (Keim 2008, 2017), where I empirically confirm the global constitution of our discipline as being marked by a centre-periphery divide. The 2010 World Social Science Report 'Knowledge Divides' confirmed this at a later stage (International Social Science Council 2010). I then brought my attention to the plethora of critiques

\footnotetext{
${ }^{1}$ Interview Ari Sitas/Wiebke Keim on the development of labour studies at UKZN, Durban, 13 February 2004, transcript available with the author.

2 wiebke.keim@misha.fr
} 
of this well-established state of affairs - calls for provincialising Europe, for deconstructing Eurocentrism and for adopting post- and decolonial perspectives. Those have partly transformed the academic landscape, especially within the North Atlantic area. But they have had limited success in challenging the fundamental global divides in production, circulation and recognition of social scientific knowledge.

Through my exchanges with Ari, I decided to adopt a different take on the question of how North Atlantic domination in the discipline could be challenged, conceptualising what I call counterhegemonic currents in global sociology. In one of our conversations, Ari remembered the emergence of South African labour studies within the context of the burgeoning of the Black labour movement from the end of the 1970s onwards. He concluded: "Because everything was happening despite institutions, despite dominant ideologies, despite everything". This encouraged me to think of the development of the sub-discipline as a counter-hegemonic current within global sociology (Keim, 2017). Differing from theoretical and deconstructive critiques, counter-hegemonic currents are effective through collective social scientific practice: through the production of data, knowledge and texts; through the breeding of new generations of scholars; and through interaction with extrauniversity actors. Their orientation towards local arenas of discussion and their production of socially relevant research effectively reduces the belief in the hegemony of the North. Gradually, integrated and productive scientific communities emerge.

In the second part of my thesis, I illustrate this process empirically. What Ari had told me about the practice of the craft in his country made me believe that South African Labour Studies were a good example to illustrate this point. I proceeded towards systematic analysis of research and teaching activities; the sociographies of the three Labour Studies Departments in Johannesburg, Durban and Cape Town; the biographies of staff members; their networks with extra-academic actors; international cooperation patterns over time; contents of major publications and publication strategies, including the South African Labour Bulletin and three monographs. The collection of documentation and written sources was complemented with interviews in order to gain insights into the oral history of the South African labour studies community. I concluded that over time, South African social scientists have generated knowledge on labour, industry and trade unions that is 'universally comprehensible', but 'arrogantly local' and 'communally accessible'. .

Ari himself was prominently involved in their development throughout the last decades. The evolution of the field of labour studies and the argument that this evolution does correspond to my idea of counter hegemonic currents is obvious from two of his book publications on which I would like to expand here: the collection of essays from the 1980s titled The flight of the Gwala-Gwala bird (2016), and the volume Voices that reason: theoretical parables (2004). Through those two books, one can observe how from social relevance, South African labour studies developed towards theoretical relevance, i.e. the two publications put forth conceptual and theoretical innovations that can make a contribution to the advancement of the discipline, based on the author's practical experience with the labour movement.

The essays collected in The flight of the Gwala-Gwala bird focus on cultural struggle and emancipation under Apartheid. The argument of the book goes beyond economic reductionism, in theoretical terms, and beyond the workerism/populism divide in political terms. This also reflects the particularity of Durban as a site of production in South African labour studies, as opposed to Johannesburg or Cape Town at the time ${ }^{4}$. Through his involvement not only as a sociologist, but as an

\footnotetext{
3 The title of the English version of my PhD features (Keim 2014) this quote from Sitas (2004).

4 This has changed since then, of course. Karl von Holdt's publication 'Transition from below' (2003), based on his PhD realised at Wits under Eddie Webster's supervision, for instance, is another original contribution of South African labour studies that takes culture and tradition equally seriously and that analyses in-depth the intersections between factory and community life.
} 
artist and an anti-apartheid intellectual, the author gained privileged insights that made their way into his sociological analyses. I shall discuss the book's contents by theme.

Essay one, 'The development of Natal's industrialisation' (1983), starts with the tour de force of retracing and synthesising the complex theoretical debate on South African economic history. It discusses basic literature in classical and Marxist economics and refutes the idea of 'two invisible hands' ruling the market and capitalist exploitation in the case of South Africa. Instead, Sitas outlines the basic features of a state-led, state-controlled economy based on racial segregation. This includes developments on how the state created conditions for low-wage black labour throughout the twentieth century through the importation of Indian indentured labour, as well as through African migrant work combined with family subsistence in rural reserves. Therefore, the alleviation of poverty cannot be understood as a natural outcome of the development of capitalist stages and of a necessary passage towards mass consumption; rather, it must be seen as the outcome of political struggles. The text then turns towards the changes introduced in the 1970s, with the rise of a more capital-intensive industrialisation, more stable employment, the growing urbanisation of a black workforce and as a consequence the reversal of urban-rural relationships (from subsistence in the rural areas to dependence on remittances from urban residents).

The Durban strikes of 1973 are depicted as the first step towards the emergence of an independent trade union movement. The author insists on the slow, difficult and uneven process of trade union organisation after 1973, as opposed to more simplistic or sanitised accounts. Based on insights from earlier phases of trade union activity and learning from their failures, the strategy from 1973 onwards was to build unions up from the ground in the factories, based on strong, democratically controlled shop steward structures and a clear focus on closely labour-related forms of struggle. However, as the overall context changed - Soweto 1976; the international anti-apartheid solidarity and its pressures on government and industries; the 1979 Wiehahn Commission - the unions faced the dilemma of restricting themselves to demands at the level of production (confrontation with capital) or also acting on the level of reproduction, which would involve a confrontation with the state.

As power relations shifted, from the 1980s onwards, management had to tone down its repressive practices and get involved in various forms of confrontation and negotiation. Sitas insists that ' $[t]$ o assume that this is a natural outcome is to ignore a long, protracted, bitter and often violent struggle to get there' (Sitas 2016, 38).

Essay two, 'Accomodation and resistance in a large mass-producing factory, c. 1940s-1980s' (1984) takes the September 1984 Dunlop strike as its starting point. A four-week strike ended with the reinstatement of all 1200 striking workers. 'This essay seeks to assert the proposition that the friction, the sparks, the explosion and the discipline of the strike was the consequence of a collision between a strong, confident shop-steward leadership and the traditional managerialism of a tough, anti-union company. Furthermore, that behind that collision, rooted deep in the history of Black working-class experience, there has been tradition over opposition and adversity' (Sitas 2016, 44).

The thorny issue of tradition is a theme that runs through the whole collection of essays. It is discussed outside the confines of established sociological thought and with all its ambiguities. As a result of continuity of employment, Dunlop was one of the few factories where several generations of workers succeeded each other, allowing a long-term collective memory to emerge: 'There was in the factory, not so much as an informal organisation of workers, but a criss-cross of reference groups, leaderships and brotherhoods. It was made up of a multiplicity of defensive combinations of workers and a repository of useful public knowledge. It demarcated an "us", which belonged together and a "them"' (Sitas 2016, 50). The concrete life and work experiences of several individuals are characterised in detail. This leads to a complex panorama of adverse yet entangled trends starting from the 1950s and 1960s: the economism of poor and exploited workers demanding better working conditions and payment; the national consciousness developing among Black workers; its 
link to traditions from the rural areas; the impacts of a changing context with the ban on opposition political parties, resettlement and its devastating impact on social networks; as a result, the lack of trust in townships conditioning a 'moral counter-revolution' with the emergence of vigilante organisations and the strengthening of Inkatha in urban areas; finally, MAWU's struggle to build up union structures within Dunlop from the 1980s onwards, leading to the 1984 Dunlop strike and the union's success.

Essay five, 'Durban's carnage: where wealth and power and blood reign worshipped Gods...' (erroneously dated 1975, since it starts by discussing events that took place between August 1985 and 1990) continues with an analysis of the roots and of the actors involved in the political violence unleashed in August 1985 in the Durban area. This was certainly an important piece of writing at the time, since media coverage proved insufficient in order to understand, beyond the attacks on people and material damages, who the rioting crowds and what the interests at play were.

The analysis presented here connects with the previous essays. It starts by outlining clashes that occurred in Durban's townships. On the one side, there were the specific interests of the black urban petite bourgeoisie, composed of traders and businessmen who had a material interest in the monopolisation of an ethnically secluded market resulting from the apartheid system, establishing a tight patronage system within the townships. It also included civil servants and teachers. The example of leader A.W.G. Champion's career illustrates the logic at play. This petite bourgeoisie had accumulated some power and wealth within the townships despite apartheid capitalist structures, actually profiting from them because it secured a closed, privileged market and spheres of influence. These fractions formed the leadership of the urban branches of Inkatha. The introduction to the volume adds that the links between Inkatha and state security apparatus were not yet clear at the time of research. This does not alter the basics of Sitas's analysis in terms of socio-economic classes and their specific interests within the economic and political system. On the other hand, a different segment of the petite bourgeoisie, composed of professionals, intellectuals, clergymen, students and youth, was at the core of Charterist politics that also counted on a strong workers' constituency.

With rich detail gained from direct insights, the article provides the historical and socioeconomic backgrounds to these events and elaborates at length on the conflict and struggle those conditions generated. Its theoretical contribution lies in the overlap of and tension between workers' economism and the expression of urban class interests, on the one hand, and the appeals of nationalism and Zuluness with its ties to the countryside on the other, providing a basis for populist and ethnic mobilisations. The latter explains Inkatha's large backing among workers: 'Inkatha had by 1983 significant worker support. It was a myth that it was located in the countryside alone. Inkatha's worker support extended beyond the assumed stereotypes of illiterates, migrants or elderly people. Of course Inkatha had a resonance through its oral spectacles and ritual displays of power among a less literate public. It must also have had an influence through the patronage systems, which cut into working-class communities. It also exerted influence and control over migrants in the hostels through similar patronage systems buttressed by councillors and indunas. It finally had support among women who, for a complex of reasons were committed to the preservation of order, custom and stability in the urban areas. A more important question was to what effect Inkatha had incorporated in its discourses and practises the needs and aspirations, anxieties and desires for an urban working class?' (Sitas 2016, 106). Inkatha functioned as a 'moral rearmament movement', responding to fragmentation through geographical and social relocation and to alienation in the working process with the rhetoric of Zulu dignity and cultural liberation as fundamental ingredients of its populism. Alongside those petite bourgeoisie fractions, a third huge political force then appeared: black trade unions. The essay traces the history of their emergence, their political role and the changing context with the formation of the UDF.

So much contextualisation is necessary in order to understand how a protest led by schoolchildren could turn into a violent riot, the Durban carnage. This event led Inkatha to establish itself alongside police and defence forces as the major guarantor of order and control. Inkatha 
therefore became the target of the popular insurrection. The essay, which had up to that point taken the form of a thorough analysis, then turns into an account of recent or ongoing events, where the author has less hindsight but provides more factual detail on the unfolding events. Finally, the author addresses the question of possible trade union strategies: remain factory-centred, focused on workers' issues and on the economic struggle against management; or move into the communities and take on the political struggle. This proved a difficult choice to make considering their situation: 'At one level the unions were at an advantage over all other organisations of the oppressed. They had the capacity to unify on the shop floors, what apartheid structures and territorial segregation kept apart: the African and Indian workers, the "urbans and the migrants", those under homeland self-government and those under Administration Board supervision (and at the same time women and men). This capacity was also a weakness; it stopped at work and the struggles around it, whereas political activity happened physically on a colour basis and at a local level inside regionally segregated residential concentrations. Whereas State power was inaccessible to all Black people, even those who have entered the new tricameral dispensation, its translation into local control of a black population was dispersed and confusing. Inanda was nowhere, Umlazi and KwaMashu are in KwaZulu, Chatsworth and Phoenix in South Africa but outside, Durban, Clermont and Lamontville exist also in South Africa but under a previous dispensation of Administration Boards. It becomes difficult to find access to a coherent regional political approach' (Sitas 2016, 126).

The political approach advocated by the author includes focusing on issues-based politics; reaching out into townships; committing to more analysis and reflection on the meaning of the nonracial basis of trade unions; and challenging Inkatha's discourses, to the extent that trade unions should strive towards hegemony. These read like sociology-informed recommendations. What is remarkable here is that although the author's own political position is clear, other viewpoints and logic are taken equally seriously. Throughout the text, popular support for Inkatha becomes understandable, and the difficulty and complexity of the situation is made obvious, as is the depth of conflicts and the challenge of finding solutions.

Essay nine, 'Class, nation, ethnicity in Natal's black working class' (1987) delves further into unfolding events by analysing the mass participation in the 1986 Inkatha May Day rally in Durban. The text is based on studies of the Labour Monitoring Group. From the Durban carnage onwards, '(...) Inkatha was forced to move away from a politics of hegemony to a politics of control. It had to rely more on paid amabutho drawn from the "lumpenproletariat" or the services of the KwaZulu police. Furthermore, its UWUSA strategy failed to proselytise significant numbers of workers in Natal. The unproblematic link between "Zuluness" and Inkatha has been broken, and this breaking has not only involved people who have understood the Zulu movement to be a narrow, particularistic, tribal, ethnic movement, but also by Zulu nationalists who felt they were betrayed' (Sitas 2016, 205). In fact, Inkatha's ideology rested on three core ideas: its lineage with the Shakan revolution and the foundation of the Zulu nation; its embodiment of a continuation of Luthuli's ANC, the real ANC, as opposed to the ANC in exile; the preservation of Zulu ways of life, including morality, discipline, patriarchy and respect.

The appeal of this ideology among urban workers complicated the picture for potential trade union strategies. Apart from lessons learned from the historical SACTU experience (see the early sociological reflections on this, presented in Webster 1978), there was a necessity to build a strong labour movement on the shop floor around strictly labour-related issues in the first place, removed from broader politics in order to circumvent the impact of Inkatha's nationalism on sections of the workforce. Despite this trade union strategy, in Natal, references to the nation and to ethnicity/Zuluness had always been made and allowed to create horizontal solidarity beyond and across class divides.

At this point, the author engages in a theoretical discussion of Ernesto Laclau's works on populism, which is further pursued in the appendix. He takes issue with Laclau's assumption that populist leaders interpellate potential followers by providing ideological constructions that voice 
their demands and that this is what turns them into political subjects. In contradistinction, Sitas stresses the importance of orality and of subject construction from below as opposed to interpellation through dominant institutions or actors.

All collective actors involved in the struggles in the Durban area shared orality as a means of subject construction. The difference between them was that Inkatha indulged in authoritarian populism, legitimating leadership through the founding myth of the Shakan revolution, whereas popular democratic movements were rooted in the common experience of dispossession and the idea that common identities arise from common struggles. Their leadership mandate was based on the idea of a temporary contract arrangement. In the latter case, political mythologies, yet present, were more ambiguous than in the case of Inkatha. One of the major achievements of the article is to demonstrate empirically that different traditions of resistance coexisted in and around Durban. An in-depth analysis of four urban areas reveals that Zuluness involved different experiences from area to area, depending on the populations' different experiences of apartheid, their distinctive ruralurban links, their visions of traditional and legitimate leadership, the different statuses of their locations and their particular experiences of migration, resettlement and proletarianisation.

Essay ten is an addendum, 'The struggle over leisure: Durban's workers, culture and education' (1987), co-authored with Debby Bonnin. It presents an empirical survey on cultural practices among workers, illustrating most of all their extremely limited time for leisure, cultural activities and reading. This lays the ground for essays that take a closer look the cultural movement, where the author draws on his own experience and involvement, unpublished mimeos, $\mathrm{MA}$ and $\mathrm{PhD}$ theses, grey literature of the emerging movements, alongside established approaches in the field - most importantly Marx - which are dismissed, corrected or modified on the basis of all the other sources.

Essay three, 'The voice of the factory' (undated) is an introductory essay on the significance of work songs, i.e. songs at work, for the South African Black working class. It shifts the focus to the cultural side of trade unionism and workers' struggles and the emergence of workers poets that play a key role in the following essays: 'Qabula contributed with his songs, which provided another log to guarantee its soaring. In the meantime, he continued to compose in his head at work. The work song survived stubbornly in the midst of noise and despite the fire and brimstone' (Sitas 2016, 77).

I will elaborate on the idea of this stubbornness of cultural creation and activity below. Essay four, 'Culture and production' (1984), draws on the author's involvement in workers' theatre with the Junction Avenue Theatre Company from 1979 onwards. It provides an aesthetic theorisation of workers' theatre in the South African context. Existing theoretical approaches (Lukacs, Brecht, Benjamin, Macherey, the contributions of the Négritude movement, Fanon) are deemed ill-suited to addressing the social, political and most of all material circumstances of South African workers' plays. The author expands on the ties between theatrical performance in work plays and popular culture. Emphasis is placed on matters of space, on the peculiarities of physical spaces (not institutions) in which workers' theatre was performed: open fields, hostel yards, streets, churches, soccer clubs, shebeens, trade union halls.

Popular culture appears as an oppositional force through which people build new collectivities and senses of self and of the social, refracting alienation and proletarianisation, in an attempt to control their conditions of life. Sitas speaks here about 'defensive combinations', 'normative communities' and 'cultural formations', three key concepts in his work. One of the weaknesses of the book certainly is that those key concepts, although used in most of the essays, are not thoroughly defined anywhere. The reference remains Sitas's unpublished PhD thesis, where he first coined those terms, but which remains inaccessible to readers. This is unfortunate, as this publication could have been an opportunity to fill this gap and clarify what will remain basic concepts for the understanding of the authors' lifework initially elaborated within the framework of his unpublished $\mathrm{PhD}$, but apparently we will have to wait some more. 
Retracing a brief history of popular culture and theatre in the country, Sitas notes that theatre had until then not been a major part of South Africa's working-class traditions. In the 1970s, the appropriation of a previously dominant cultural form by an oppositional, bottom-up cultural movement generated a series of contradictions. The article outlines the extent to which these contradictions were productive and creative: First of all, how could work as a real site of oppression be represented on stage? 'Any mimetic idea of portrayal of the gigantic productive forces of modern industry is idle tale, yet something needs to be portrayed' (Sitas 2016, 86). Workers' theatre experimented with two choices, either revolutionising the stage or finding adequate metaphors. It turned out that the invisibility of the experience of exploitation was most aptly expressed through narrative. Second, the clash of moral orders to happen in the movement had to be displayed on the stage. New forms of workers' association gave rise to new moral orders, clashing with the practices of old cultural formations and their expectations, including confrontations between urban and migrant, worker and thug, irresponsible worker and powerful shop steward, drunkard and trade unionist. Thirdly, while traditional forms of popular expression used to highlight individual characteristics, workers' theatre had to depict workers as a group and a driving force of social processes on stage, and in doing so emphasise the class aspect. Unfortunately, here, Sitas does not expand on his brief comment that this had adverse effects on women, since factory work and equal roles as actors in social processes could potentially emancipate them from subordinate roles. Fourthly, the different temporalities involved in traditional ways of narrating events contrasted with the acceleration needed for staging workers' theatre. Fifthly, there were contradictions between different genres and functions of cultural performance to contend with. For example, conventional mythological narration as opposed to the newly de rigueur realism, the traditional role of singing as opposed to the role of songs on stage in plays, etc. Lastly, scholars in the field of aesthetics had to situate workers' theatre within popular culture to shed light on its aesthetic specificities.

Essay six, 'The flight of the Gwala-Gwala bird: worker culture in Natal's labour movement' (undated) links the works on culture back to the more general socio-economic and historical analyses outlined above, highlighting the theoretical importance of an in-depth, empirically infused understanding of the significance of the cultural movement for the overall theorisation of the black workers' movement, but ultimately also for trade union strategy: 'I argued that these plays could not so easily be dissolved into a "proof" or a demonstration of one "paradigm" over another. My plea was for a more adequate theorisation of popular and working class cultural formations and a better understanding of these plays as events of a peculiar kind of "cultural spaces" occupied by Black people in South Africa' (Sitas 2016, 133-34). I shall pursue this line of thought further below in the section on the parables. It also informs the ongoing work in the Deviance/Defiance research cluster (Sitas et al. 2014), insisting on a much broader historical and global perspective on the issue of the complexity, overlap, tension, contradiction, and multiplicity of voices that draw their legitimacy from the complexity and difficulties of specific living conditions.

The aim of essay six was to contribute to the then ongoing debate on working-class culture within South African academia, and on its relationship to three resistance movements - Black Consciousness, the popular-democratic movement and the democratic trade unions. Again, one faces here the question of the entanglement between class and populism, and between tradition and culture. The Dunlop play had been a major trigger for the cultural movement that spread throughout Natal, with the creation of staffed workers' cultural locals from the middle of the 1980s onwards, confirming that the unions took cultural work seriously. Especially in the aftermath of political violence in 1985, campaigns aimed at fostering worker unity based on cultural work outside of dominant institutions. The political and ethical premise was the idea of 'creating tomorrow today', i.e. ideas and practices implemented today were supposed to prefigure the desired future society. Beyond mere propaganda or diversion, this turned cultural activities into 'a site of struggle in [their] own right', with cultural transformation as a goal. However, the intentions and determination of cultural and worker leaders alone seemed insufficient to explain the spread of the cultural 
movement: 'What has sustained it, is what has been identified as "the customs, habits and rituals of Zulu people in Natal"' (Sitas 2016, 144).

Their traditions, legacies and ethnic pride were crucial for the emergence of cultural work conveying alternative imaginaries of human flourishing and dignity. In this sense, classic pieces like Hlatshwayo's poem 'Black Mamba Rising', celebrating the successful Dunlop strike, or Qabula's 'Praise Poem', integrating the tradition of imbongi but also of lay preachers, provided mobilising metaphors that were taken up in everyday struggles of workers. They included references to African and Zulu pasts. They contributed novel values to the ongoing struggles, extending, playing around with and ultimately undermining tradition to create new artistic and political forms. In this sense, Sitas confirmed that the working class was not just a 'tabula rasa' but was grounded in a multiplicity of traditions, not necessarily class-based.

Essay seven, 'Traditions of poetry in Natal' (undated) pays tribute to two coexisting strands in poetry, one written and the other one oral. Examples of the former include Dhlomo, a poet whom Sitas situates in the progressive Black petite bourgeoisie, and his attempt to enhance national projects; Kunene, another gifted poet, but distanced from the 'actual contents of oppression and exploitation', 'dislocated from the immediate structures of feeling and the rhythms of resistance of a modern day industrial proletariat' (Sitas 2016, 167); as well as Gwala, whose poem '(...) the Children of Nonti was an Africanist affirmation of pride and dignity with few equivalents in the 1970s; but it is a Black consciousness soaked in working-class grit. With him the universe shrinks' (168). With literary expertise, Sitas outlines the differences between those three poets, their individual particularities, their position within the artistic and political field, as well as cross-references between their writings. This is a contribution to South African literary history as well as a homage to each of them for their contributions to black poetry and black struggles. A fundamental tragedy connects all three: although their poetic forms were based on imbongi or people's poetry, i.e. on the assumption of a direct communication with the audience, they did not find that audience, as 'they will not be read unless their works become "orally" accessible, and the people will not read until conditions that make reading possible prevail in their lifetime' (Sitas 2016, 171). This statement hints to the empirical work published with Debby Bonnin (see above).

In sharp contrast, Sitas then portrays the newly revived oral poetry of Vilane, Zondi, Hlatshwayo and Qabula. This workers' poetry was indeed orally performed in cultural locals that served as venues for workers, communities and youth to meet. Their return to orality, instead of the hegemonic scripted format, allowed for a direct connection to and a major impact on people's struggles. The article provides an outline of the careers of the four mentioned poets. Their poetry was 'the consummated result of a struggle by people who had a large immediate audience, a clear organisational project, to create a popular poetry that is of the people, as the people were changing themselves and the world around them' (Sitas 2016, 179-80).

Essay eight, 'The voice and gesture in South Africa's revolution: a study of worker gatherings and performance genres in Natal' (1990), complements the aesthetic argument of essay four, providing a sociological analysis of the cultural movement and of the role of performances in it. It proposes an analysis of artistic performance in mass gatherings, questioning the relationship between crowds and oral performers. Unlike in traditional acts of mass communication, the author observed organised events with set agendas that happened within constrained material spaces with certain limitations, and that were acted out and embedded in power relations. The sociological approach precludes from indulging in romanticising visions of those events. Among others, the essay makes an important distinction between the grassroots control observable in those mass gatherings and grassroots democracy, which required more than gathering people around a leader with a microphone. In any case, the function of those mass meetings was to create an emotional basis for a mass movement; the affirmation of 'manufactured identities and comradeship' and of a sense of belonging; as well as the demonstration of resistance and defiance. 
To conclude, regarding the involvement of Sitas in the cultural struggles, I would like to pick up on Pitika Ntuli's astute suggestion, during Ari's September 2017 retirement celebration at UCT, that he was not alone in this endeavour. Astrid von Kotze's contributions are adequately referenced throughout the pages of this collection of essays. I am not sure, though, whether readers who are unfamiliar with Ari's personal background get a genuine sense of her importance in the preparation and success of the worker plays in which they both were involved and in which she seemed to be the driving force.

Ari's claim that since 1990, '[a]cademy moved on, seeing the meta-narratives articulated here as suspect and limited' (Sitas 2016, 9), might be accurate. However, upon rediscovering the sharp analyses of the ongoing struggles presented in this book, in retrospect it transpires that readers could already get a sense of the complexity of problems and frustrations that the country would struggle with until today. As Sitas convincingly argues in the introduction to this collection, '(...) the essays argue that the Black working class had developed more than a trade union consciousness; rather many of its components have developed unique and exciting visions. It is the neglect of these visions by many trade unions during the last two decades that has precipitated the deep social crises of our recent days' (Sitas 2016, 13).

A deeply unsettling book for the conventional sociologist, the Theoretical Parables (Sitas 2004) pick up an argument first formulated in Gwala-Gwala Bird: '[m]ost theoretical and practical insights in these essays come from the way in which people and their ideas struggled with the limits and pressures of structures and processes' (Sitas 2016, 13). As in the earlier African indigenisation debate, and in line with the author's earlier works, the focus here lies on the sociological significance of bodies of knowledge from orally shaped cultural contexts. This methodological choice arises out of Ari's personal experience as a university-based intellectual involved in community activities that encouraged him to seek to bridge the gap between academic and non-academic discourses: 'I argue, instead, that the fence between the citadel of knowledge and science and the fields needs cutting. The problem contexts of the questions we need to answer will have to be a negotiation with the Mshengu, the Shelelembuzes and others, learning is everywhere and theorising too. (The parables' project, W.K.) asks of knowledge and reliability to be people-centred, generously abstract and contextually moral' (Sitas 2004, 69).

The first part of the book recounts a number of parables from the KwaZulu-Natal region. These texts take cultural knowledge, process it both creatively and theoretically and present it in a form that is typical of the representation and transmission of knowledge in oral cultures. The adjective 'theoretical' gives them a 'sociological surplus value'. These parables were opened up for discussion in university seminars and local communities. Together with the people from whose communicatively competent life worlds the themes, form and method are taken, Ari discovers their viewpoint and interpretation of South African society and their problems - from exploitation and oppression under apartheid and the experience of migrant labour and urbanisation to transition and globalisation.

Contents vary: basic sociological assumptions are reconsidered, a variety of theoretical approaches are discussed and challenged, and new concepts are introduced. The focus is always on a modernity that did not come with the transition from feudalism to capitalism, but with colonialism. In all parables, the main takeaway is that modern institutions - factories, prisons, universities discipline individuals, sometimes causing their navigation systems, their cognition, language and interaction to break down as in the case of this young woman who migrates from her rural home place to the city: 'The girlwoman experiences disoralia - an inability to establish parameters for meaningful communicative practice; disvaluation and degendering - she is not only a notwoman she is a new thing. She had already been told that the curse of her line was to visit her. In transgressing values and norms, in following the sounds of the letters (of her lover, wk), she is leaving a significant value system' (Sitas 2004, 90). 
This can lead people to act disoriented, traumatised or demented. However, there is always a certain degree of dissonance, resistance, and imaginative transgression between each individual and social institutions, an asymmetry between structure and action, system and practice, interpellation and subjectivity. Here, the most recent book links into the insight on the stubbornness of the work song formulated in the Gwala-Gwala bird collection: resistance to institutions, structures and systems in the agency and subjectivity of individuals and communities - an insight Ari had gained from his engagement with workers, observing how they coped with factory life. In Voices That Reason he takes this insight further.

'He had taken all the spiritual counsel he could take and the strong medicines from the inyanga from near Umgababa. For good measure he spoke to the priest, who reminded him of the story of Job, so when they arrested him he could withstand anything.

At the end of the day he would look at the soft parts where his nails should have been, the raw parts next to the cooked parts on his genitals where electricity was applied, his inflamed kneecaps from standing on one leg and then the other, and he would sing and think of his three friends and his loved ones and dream of a big feast.

The next day his eyes were so swollen from the blows that he could not examine the pains and the wounds on his body. He could only think of his two friends and his loved ones and dream of a big feast. His third friend's voice was played to him on a voice machine, betraying him.

The next day he sat half-blind and his mouth swollen, so that the stiff porridge could not find the way to his stomach. He could only think of his loved ones and dream of a big feast. The death of his friends was played to him on the radio news.

The next day he was brought back, carried in a hessian bag, and dropped on the floor. He could only think of a big feast for the neighbourhood's poor. It was whispered to him from warder to warder that his loved ones were no more.

Throughout these days or years he said nothing. He only went mad and started to try and eat himself up when they confirmed that the world had died' (Sitas 2004, 87-88).

In light of the hardships and toil that the characters in the parables endure in their dealings with institutions, the postmodern assumption of a decentred subject reads to the author as a 'privileged piece of superficiality': 'Such a conception confuses roles, strategies and behaviour with the struggle to "centre" our navigating mechanisms, to steer through a maze of pressures and processes. The active, refracting and recoiling agency (...) must not be confused with the autonomous subject of bourgeois enlightenment, but (...) when it "gives in", the result is fragmentation, a dispersal into meaninglessness and de-rangement, infraction' (Sitas 2004, 102).

The parable project questions a wide range of sociological certainties, by temporarily removing the distance between sociologist and object, a foundation of the discipline since Comte. This is not primarily intended to deconstruct and uncover power relations between researcher and object, but to experiment with a shared process of discovery and theorising.

The Theoretical Parables reflect Ari's experience in research, teaching and engagement with social and political movements, as the following passage makes clear: 'The "researched" talked back, argued, resisted the classifications and pointed out that the researcher, professor sir or madam, was also part of the field, part of its domain' (Sitas 2004, 41). At this point, I claim in my argument on counter hegemonic currents, social relevance transforms into theoretical relevance.

As in many of his works, Ari draws on both classic and postmodern theory, valuing and criticising both in equal measure and on a fundamental level. His aim is nothing less than to present a South African sociology that is 'neither pre-modern, nor modern, nor post-modern', 'universally comprehensible', simultaneously 'arrogantly local' and 'communally accessible' (Sitas 2004, 23). While the essays collected in The Flight of the Gwala-Gwala Bird clearly address a South African 
audience and can be difficult to grasp for foreign readers lacking knowledge of the South African historical, political and intellectual contexts, Voices that reason reflect Ari's rapid internationalisation after the end of the academic boycott and the opening of the country that coincided with his leading roles within SASA and within the ISA Executive. It is written for the world community of sociologists. Voices that reason puts an end to the South's lament over dependency, irrelevance and marginality and at the same time defends itself against hegemonic and marginalising tendencies in the international scholarly community. Ari's contribution to the discipline can justifiably claim to be both universally comprehensible but arrogantly local. 


\section{References}

Holdt, Karl von. 2003. Transition from below: Forging trade unionism and workplace change in South Africa. Pietermaritzburg: University of Natal Press.

International Social Science Council, ed. 2010. World Social Science Report 2010. Paris: Unesco Publishing.

Keim, Wiebke. 2008. Vermessene Disziplin: Zum konterhegemonialen Potential afrikanischer und lateinamerikanischer Soziologien. Global studies. Bielefeld: Transcript.

Keim, Wiebke. 2017. Universally comprehensible, arrogantly Local. South African Labour Studies from the Apartheid Era into the new millennium. Paris: Editions des Archives Contemporaines.

Sitas, Ari. 2004. Voices that reason - theoretical parables. Pretoria: University of South Africa Press.

Sitas, Ari. 2016. The flight of the Gwala-Gwala bird. Essays by Ari Sitas. Cape Town: South African History Online.

Sitas, Ari, Wiebke Keim, Sumangala Damodaran, Nicos Trimikliniotis, Faisal Garba. 2014. Gauging and engaging deviance, 1600s-2000. Delhi: Tulika Books.

Webster, Eddie, ed. 1978. Essays in Southern African labour history. Ravan labour studies 1. Johannesburg: Ravan Press. 